\title{
Preparation of ethoxyquin salts and their genotoxic and antioxidant effects on human lymphocytes
}

\author{
Alina Błaszczyk ${ }^{a}$ and Janusz Skolimowski ${ }^{b, *}$ \\ ${ }^{a}$ Department of Cytogenetics and Plant Molecular Biology, University of Łódź, \\ Banacha 12/16, 90-237 Łódź, Poland, \\ ${ }^{b}$ Department of Organic Chemistry, University of Łódź, Narutowicza 68,90-136 Łódź, Poland \\ E-mail:jskolim@uni.lodz.pl
}

Dedicated to Prof. Jan Epsztain on the occasion of his $75^{\text {th }}$ birthday

\begin{abstract}
Ethoxyquin phosphate (EQ-P) and ethoxyquin hydrochloride (EQ-HCl) were synthesized and studied for genotoxic and antioxidant activities with the use of comet assay and micronucleus test performed on human lymphocytes. The results were compared with the activities of the earlier studied ethoxyquin (EQ; 1,2-dihydro-6-ethoxy-2,2,4-trimethylquinoline), a strong antioxidant used mainly as a preservative in animal feeds. Study has demonstrated genotoxic activity of EQ salts in the comet assay performed on human lymphocytes but micronucleus test indicated that the substances are safe to use. EQ salts were significantly less effective in inducing DNA fragmentation than EQ. The protective effects of the studied compounds against $\mathrm{H}_{2} \mathrm{O}_{2}$ induced DNA damage were also observed only in the comet assay. The antioxidant activity of EQ-HCl was slightly higher than that of EQ-P but the difference was not statistically significant. On the other hand, both EQ salts were weaker protectors from the effect of $\mathrm{H}_{2} \mathrm{O}_{2}$ than EQ itself.
\end{abstract}

Keywords: 1,2-Dihydroquinoline, ethoxyquin salts, hydrogen peroxide, micronuclei, comet assay, human lymphocytes

\section{Introduction}

Ethoxyquin (EQ, 1,2-dihydro-6-ethoxy-2,2,4-trimethylquinoline) is a synthetic antioxidant widely used mainly to preserve vitamins and lipids in animal feeds, but also as a preservative in dehydrated forage crops, as an antiscald agent in pears and apples, and as a color preservative in spices. ${ }^{1}$ EQ is the cheapest and most effective in extending the shelf life of animal feeds and FDA (Food and Drug Administration, USA) approved it for use at 150 parts per million. ${ }^{2}$ EQ has 
been used in animal feeds since 1959, but only in the late 1980s, following wider introduction of this chemical to dog foods unusual disorders were observed in the animals. ${ }^{3,4}$ At that time many companies also started adding extra EQ to animal feeds because of easily oxidized high-fat content in these products. ${ }^{5}$ Moreover, it was stated earlier that commercial EQ could contain even $20-30 \%$ of the material of unknown nature ${ }^{5}$ which was present in animal feeds together with EQ and could also affect animal health. Commercial EQ can be readily purified and converted into stable salts, ethoxyquin phosphate (EQ-P) or ethoxyquin hydrochloride (EQ$\mathrm{HCl}){ }^{6}$ The use of EQ in the form of salts would make it possible to add a known amount of pure EQ to animal feeds without adding unknown compounds which are present in commercial EQ. It could improve the safety of EQ use as antioxidant, but so far there are very few papers dealing with the biological properties of this compound in the form of salts. ${ }^{6,7}$ Makary et al. ${ }^{8}$ showed that this compound administered as EQ-HCl, similarly as EQ, significantly increased liver weight and protein content along with hepatic glutathione transferase and glutathione reductase activities in five used mouse strains. $\mathrm{Kim}^{6}$ studied the dietary effects of EQ-HCl in female ICR mice; the animals were fed ground feed containing commercial EQ, EQ-HCl or no additive. The comparison of EQ and EQ-HCl effects showed that the animals in EQ-HCl group initially lost weight less than the EQ-group, but then gained it faster. ${ }^{6}$ It was also shown that EQ-HCl provided protection against toxic doses of pyrrolizidine alkaloids, and its activity was comparable to that of commercial EQ. ${ }^{4}$

In our laboratories we have undertaken studies on cytotoxic, genotoxic and antioxidant activities of EQ (purity > 97\%) and new potential antioxidants (including different EQ salts) ${ }^{7,9-11}$ after reports on harmful health effects observed in animals fed with EQ-containing feeds. ${ }^{1,3,12}$ The biological properties of EQ were evaluated on human lymphocytes as studies on mammalian and human cells were recommended. ${ }^{12}$ The search for new antioxidants which could be used as preservatives to replace EQ were also conducted by others scientists. ${ }^{13,14}$

Our earlier in vitro studies showed that cytotoxicity of ethoxyquin salts (phosphate and hydrochloride) differed from that of pure EQ. ${ }^{10}$ In the MTT test performed on human lymphocytes with the use of EQ, EQ-HCl and EQ-P $\mathrm{IC}_{50}$ values (the compound concentrations that effectively inhibit $50 \%$ of cell growth) were determined after 72 -h treatment. ${ }^{10}$ It was shown that cytotoxic activity of EQ-HCl was only slightly lower than that of EQ $\left(\mathrm{IC}_{50}: 0.13 \mathrm{mM}\right.$ and $0.09 \mathrm{mM}$, respectively), but when EQ-P and EQ were compared the difference was more significant $\left(\mathrm{IC}_{50}\right.$ for EQ-P was $\left.0.8 \mathrm{mM}\right) .{ }^{10}$ The activities of EQ and its salts were also evaluated by the use of the TUNEL method detecting the fragmented DNA of apoptotic cells labeled with fluorescein at 3 '-OH ends. ${ }^{10}$ EQ induced significant increase in the number of apoptotic cells with fragmented DNA when it was used at the concentrations of $0.05,0.1,0.25$ and $0.5 \mathrm{mM}$ (the respective percentages of apoptotic cells were 3.6, 8.2, 42.4 and 83.0). ${ }^{10}$ After treatment with EQ salts an increase in the number of apoptotic cells was noted only for EQ-HCl used at the concentration of $0.5 \mathrm{mM}$ (5.2\% of apoptotic cells).

In the present study the genotoxic and antioxidant potentials of EQ-P and EQ-HCl were investigated by the comet assay and micronucleus test. To our knowledge there are no published 
data on genotoxicity of these EQ salts; antioxidant activity was reported only for EQ-HCl in the in vivo experiments with mice. ${ }^{6}$

\section{Results and Discussion}

\section{Chemistry}

The EQ phosphate (EQ-P, CAS number 3658-72-8, purity > 98\%) and EQ hydrochloride (EQ$\mathrm{HCl}$, CAS number 3659-01-6, purity $>96 \%$ ) as well as EQ (1,2-dihydro-6-ethoxy-2,2,4trimethylquinoline, CAS number 91-53-2, purity $>97 \%$ ) used to their preparation were synthesized in the Department of Organic Chemistry, University of Łódź (Poland). EQ was purified and converted to a crystalline EQ-HCl or EQ-P.

The synthesis of EQ (Scheme 1) was described earlier, ${ }^{11}$ but now we have a new modifications (solvent, synthesis, purification). EQ was obtained from 0.5 mol (68.6 g) pphenetidine (4-ethoxyaniline) and $0.3 \mathrm{~mol}(17.4 \mathrm{~g})$ acetone, $0.6 \mathrm{~mol}(69.7 \mathrm{~g})$ diacetone alcohol (4-hydroxy-4-methyl-2-pentanone), $100 \mathrm{mg}$ p-toluenosulfonic acid, by heating in $200 \mathrm{~mL}$ toluene with the use of Dean-Stark apparatus over $6 \mathrm{~h}$. The mixture was heated at $130{ }^{\mathrm{O}} \mathrm{C}$ (oil bath, 3h) and then toluene and water were removed from it. The trace of reagent (4ethoxyaniline), solvent and excess of mesityloxide (4-methyl-3-penten-2-one) also were removed by steam distillation.

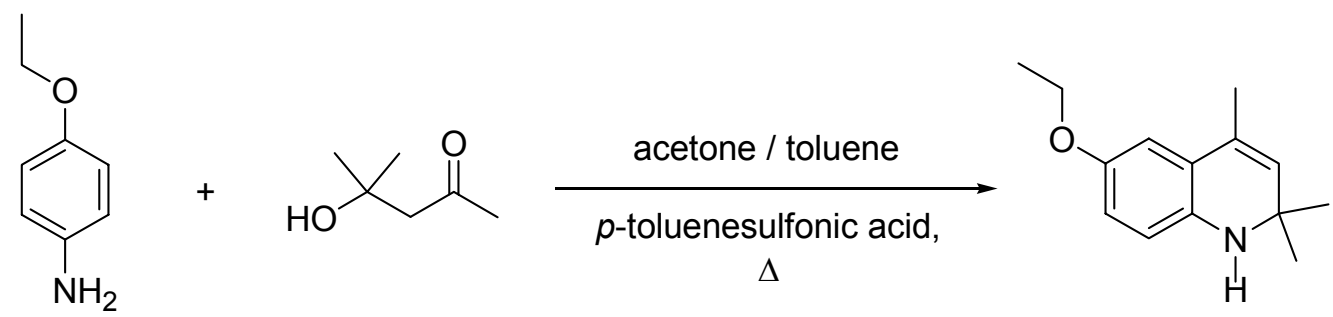

Scheme 1. Synthesis of ethoxyquin.

EQ was separated by the use of Büchi apparatus (Kugelrohr redistillation; $0.1 \mathrm{~mm} \mathrm{Hg}$ ) and a light yellow liquid $\left(\mathrm{n}_{\mathrm{D}}{ }^{20} 1.570\right)$ was obtained (45.6 g; yield 42\%). Part of the product was dimer - 1,8'-bis (1,2-dihydro-6-ethoxy-2,2,4-trimethylquinoline), and some part of it was a black polymeric solid. The blue fluorescent band from TLC identified a yellow solid as 2,4-dimethyl6-ethoxyquinoline (m.p. $85-87^{\circ} \mathrm{C}$ ).

Then EQ was purified and converted to a crystalline, stable EQ-HCl or EQ-P (Scheme 2). The EQ salts were obtained in the reaction of EQ (yellow oil; $2.17 \mathrm{~g}, 0.01 \mathrm{M}$ ) in water-acetone solution $(1 / 4 \mathrm{v} / \mathrm{v}, 30 \mathrm{~mL}$, ) with concentrated hydrochloric $(0.011 \mathrm{M}, 37 \%$ water solution, wt./v) or phosphoric acid $\left(0.011 \mathrm{M}, 85 \%\right.$ water solution, wt./v). The solutions were heated to $55^{\circ} \mathrm{C}$ and mixed with activated carbon $(0.1 \mathrm{~g} / \mathrm{mL} ; 1 \mathrm{~h})$. The hot solutions were filtered off and concentrated under reduced pressure to about $15 \%$ of initial volumes and then additional acetone was added 
$(50 \mathrm{~mL})$. After cooling $\left(5^{\circ} \mathrm{C}\right.$, ice-water bath) EQ salts slowly crystallized from water/acetone. The products were collected by filtration, washed with cold acetone $(2 \times 30 \mathrm{~mL})$ and air-dried to give EQ-HCl (1.95 g, yield 76.8\%) or EQ-P (1.72 g, yield $54.5 \%$ ). EQ salts were then recrystallized from methanol.

The regenerated free base (EQ) from the EQ-HCl was further purified by silica gel column flash chromatography to remove several minor contaminants, and the pure EQ was immediately converted into analytical salts (EQ-HCl and EQ-P). EQ and its salts_were kept in low temperature $\left(-20^{\circ} \mathrm{C}\right)$ to prevent their oxidation. Analytical samples of EQ-HCl or EQ-P (1 g) were obtained by lyophilisation from water solutions $(10 \mathrm{~mL})$ with the use of high vacuum system. The obtained products: light-beige EQ-HCl (m.p. $189-191{ }^{\circ} \mathrm{C}$ dec.; lit. ${ }^{15} 192-193{ }^{\circ} \mathrm{C}$ ) and light-grey EQ-P (m.p. $115-116{ }^{\circ} \mathrm{C}$ dec.) were soluble in water, DMSO, ethanol, trifluoroacetic acid and acetic acid.

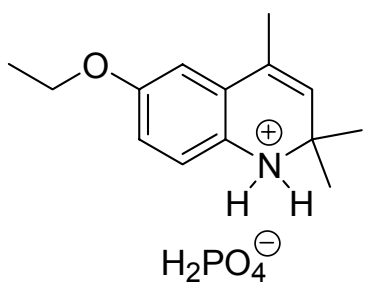

EQ phosphate (EQ-P)

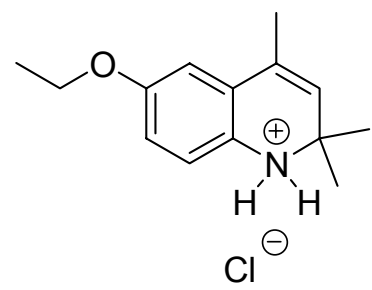

EQ hydrochloride (EQ-HCl)

Scheme 2. Chemical structure of EQ salts.

\section{Biological assays}

In the study the comet assay (single cell gel electrophoresis assay, SCGE) ${ }^{16}$ and the micronucleus test (the cytokinesis block micronucleus assay, CBMN) ${ }^{17}$ were used to examine genotoxic and antioxidant activities of EQ salts. The comet assay is a method for the detection of DNA damage in interphase cells, and it is especially sensitive in detecting DNA single-strand breaks, alkali-labile damage and excision repair sites in individual cells. ${ }^{16}$ The micronucleus test is a cytogenetic method detecting chromosomal changes like acentric chromosome and chromatid fragments or chromosome lagging in anaphase. ${ }^{17}$ Chromosomal aberrations in this test are expressed as micronuclei (MN) and they are scored in proliferating binucleated cells (after application of cytokinesis block with the use of cytochalasin B). In the micronucleus test the cell division kinetics can be also estimated as a cytokinesis block proliferation index (CPBI) is calculated. $^{17,18}$

To examine the ability of EQ-P or EQ-HCl to cause DNA damage, toxicity was evaluated in preliminary studies since it also may cause DNA damage; it was evaluated by the standard viability assay using the trypan blue exclusion test. ${ }^{19}$ It was shown that cell viability of all the dose-samples was greater than 95\%. In Table 1 the results of genotoxicity studies are presented and they are expressed as the mean values of Olive tail moment (OTM, the product of the 
distance between the center of gravity of the head and the tail, and percent of tail DNA). ${ }^{20}$ Dosedependent increases in damage level were seen $(r=0.72$ and $r=0.76$, respectively). EQ-HCl was a slightly stronger inducer of DNA damage than EQ-P, but the difference was not statistically significant.

Table 1. DNA damage in human lymphocytes treated with EQ-P or EQ-HCl for $1 \mathrm{~h}$ and expressed as Olive tail moment (OTM); the results were compared with those obtained earlier for pure EQ $^{9}$

\begin{tabular}{ccccc}
\hline $\begin{array}{c}\text { Concentration } \\
(\mu \mathrm{M})\end{array}$ & EQ-P $^{\mathrm{a}}$ & $\begin{array}{c}\text { EQ/EQ-P } \\
\text { ratio }\end{array}$ & EQ-HCl $^{\text {a }}$ & $\begin{array}{c}\text { EQ/EQ-HCl } \\
\text { ratio }\end{array}$ \\
\hline 0 & $1.32 \pm 0.21$ & 0.89 & $1.32 \pm 0.21$ & 0.89 \\
1 & $1.63 \pm 0.30$ & 4.16 & $2.80 \pm 0.54^{*}$ & 2.43 \\
2.5 & $2.48 \pm 0.41^{*}$ & 2.87 & $2.90 \pm 0.35^{*}$ & 2.45 \\
5 & $2.76 \pm 0.38^{*}$ & 2.70 & $3.75 \pm 0.49^{*}$ & 1.79 \\
10 & $3.91 \pm 0.50^{*}$ & 3.11 & $4.15 \pm 0.67^{*}$ & 2.93 \\
25 & $3.42 \pm 0.43^{*}$ & 4.23 & $4.40 \pm 0.55^{*}$ & 3.29 \\
\hline
\end{tabular}

${ }^{\text {a }}$ Data are reported as mean values ( \pm S.E.M.) of OTMs.

* Statistically significant relative to the negative control $(\mathrm{P}<0.05)$.

In Table 1 the comparison of the results of the studies on genotoxicity of EQ-P or EQ-HCl with those obtained earlier for pure EQ $(97 \%)$ in the comet assay ${ }^{9}$ is also made (the ratio of the mean values for EQ and EQ salt is given). It is clearly seen that EQ was a stronger inducer of DNA damage than EQ salts. After using the concentration of $25 \mu \mathrm{M}$ (the highest dose studied) the mean OTM value observed after EQ treatment was over 4-fold greater than that obtained for EQ-P and over 3-fold greater than that for EQ-HCl.

Figure 2 shows the distribution of the cells with different levels of DNA damage. Similar effects of both compounds can be seen. After the treatment with EQ salts cells with OTM $\leq 5$ always predominated (more than 75\%). The treatment of the lymphocytes with increasing doses of EQ-P or EQ-HCl caused increase in the number of cells with more fragmented DNA; majority of these cells were characterized by OTM values between 5 and 15. The results obtained earlier for EQ ${ }^{9,21}$ showed that after treatment with this compound the percentage of the least damaged cells $(\mathrm{OTM} \leq 5)$ was always lower than 60 . The lower genotoxicity observed for EQ salts in comparison with EQ is an advantage for compounds used as preservatives. Similar results were observed earlier for other salts of EQ studied with the comet assay (EQ ascorbate, EQ salicylate, EQ n-hexanoate, EQ salt of Trolox C); ${ }^{7}$ after EQ salts treatments the genotoxic effects were observed, but the genotoxic potentials of the EQ salts studied were lower than that of EQ. ${ }^{7}$ It is known that in the presence of oxygen EQ can be oxidized a little, but the products of its 
oxidation have also antioxidant activities; ${ }^{22}$ it is one of the reason its high antioxidant efficiency. Processes of oxidation in EQ molecule occur among others at $\mathrm{N}$ atom and as a result aminyl radical can arise (unpublished results); it can cause cytoxic or genotoxic effects. Converting EQ in the form of salt eliminates that possibility to some degree. It can be a possible reason of lower cytotoxic and genotoxic activities of EQ salts in comparison with EQ.

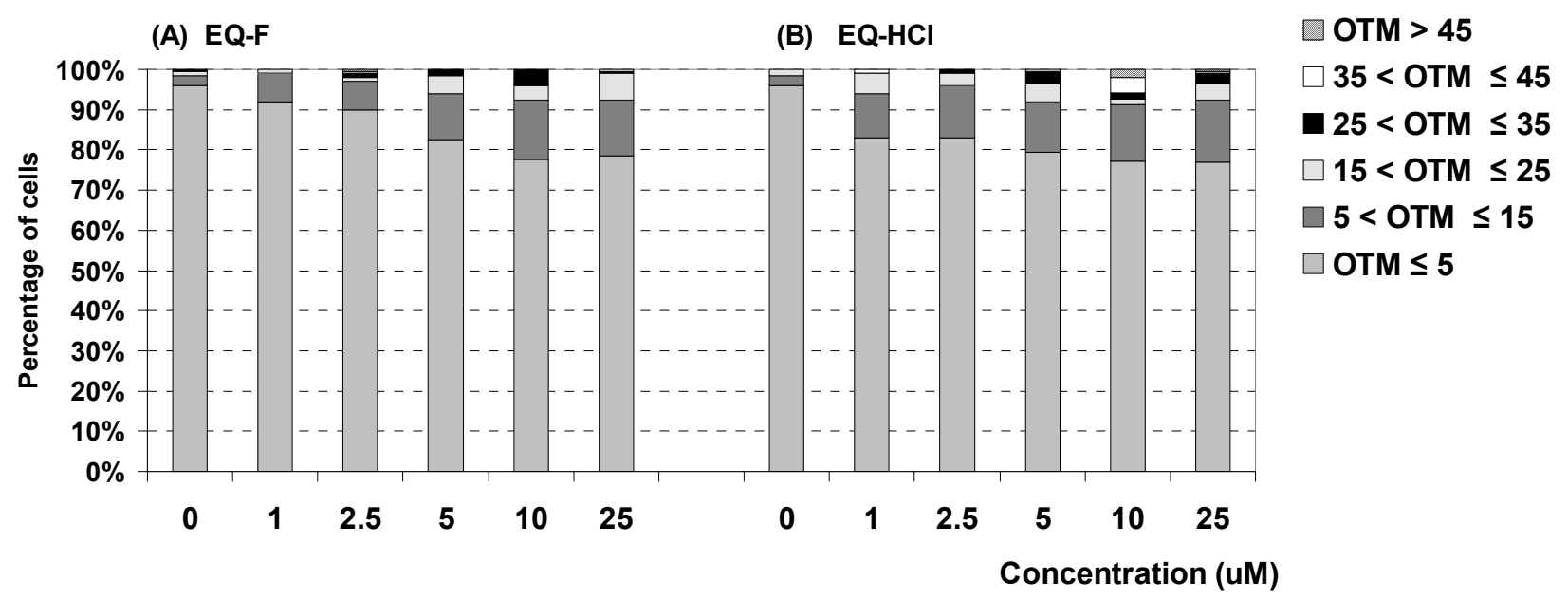

Figure 2. Lymphocytes with different levels of DNA damage induced by EQ-P (A) or EQ-HCl (B).

The data presented in Table 2 show a protective activity of EQ salts. The protective effect after EQ-P treatment was observed only when it was used at the concentration of $10 \mu \mathrm{M}$ while after EQ-HCl treatment the protective effects were also observed after its lower concentrations (1 and $2.5 \mu \mathrm{M}$ ). Moreover, the reduction in DNA damage level, showing antigenotoxicity, was always greater after EQ-HCl treatment, especially when the compounds were used at the concentrations of 1 and $2.5 \mu \mathrm{M}$, but the difference was not statistically significant (Table 2).

Antioxidant activities of EQ salts (EQ-P and EQ-HCl) were significantly weaker than that of pure EQ. ${ }^{9}$ The mean DNA damage reduction (the mean from all concentrations used) after EQ-P and $\mathrm{EQ}-\mathrm{HCl}$ treatments was $32.0 \% \pm 2.9$ and $42.7 \% \pm 2.8$, respectively, while after EQ treatment it was $66.1 \% \pm 2.6,{ }^{21}$ so these studies showed that EQ salts (phosphate and hydrochloride) did not protect the cells against $\mathrm{H}_{2} \mathrm{O}_{2}$-induced damage so efficiently as EQ. It is not in accordance with the results obtained by $\mathrm{Kim}^{6}$ who stated that the protective effects of EQ-HCl were comparable to those of EQ, but the protective effects of these compounds were analysed against toxic doses of pyrrolizidine alkaloids in experiments in vivo. 
Table 2. The effects of ethoxyquin salts (EQ-P or EQ-HCl) on $\mathrm{H}_{2} \mathrm{O}_{2}$ genotoxicity assessed by the comet assay on human lymphocytes. The cells were incubated with EQ-P or EQ-HCl immediately before exposure to $\mathrm{H}_{2} \mathrm{O}_{2}(5 \mathrm{~min}$. on ice)

\begin{tabular}{llccc}
\hline & \multicolumn{2}{c}{ EQ-P } & \multicolumn{2}{c}{ EQ-HCl } \\
\cline { 2 - 6 } Treatment & OTM $^{\mathrm{a}}$ & $\begin{array}{c}\text { Reduction } \\
(\%)^{\mathrm{b}}\end{array}$ & OTM $^{\mathrm{a}}$ & $\begin{array}{c}\text { Reduction } \\
(\%)^{\mathrm{b}}\end{array}$ \\
\hline Negative control & $1.02 \pm 0.31$ & & $1.17 \pm 0.30$ & \\
EQ salt $1 \mu \mathrm{M}$ & $1.04 \pm 0.22$ & & $1.24 \pm 0.22$ & \\
EQ salt $2.5 \mu \mathrm{M}$ & $1.08 \pm 0.75$ & & $1.18 \pm 0.28$ & \\
EQ salt $\quad 5 \mu \mathrm{M}$ & $1.19 \pm 0.23$ & & $1.46 \pm 0.43$ & \\
EQ salt $\quad 10 \mu \mathrm{M}$ & $1.01 \pm 0.28$ & & $1.34 \pm 0.36$ & \\
$\mathrm{H}_{2} \mathrm{O}_{2}(10 \mu \mathrm{M})$ & $6.29 \pm 0.83^{*}$ & & $5.83 \pm 0.63^{*}$ & \\
$\mathrm{H}_{2} \mathrm{O}_{2}+$ EQ salt $1 \mu \mathrm{M}$ & $4.63 \pm 0.77$ & 31.5 & $3.69 \pm 0.52^{* *}$ & 45.9 \\
$\mathrm{H}_{2} \mathrm{O}_{2}+$ EQ salt $2.5 \mu \mathrm{M}$ & $4.83 \pm 0.77$ & 27.7 & $3.86 \pm 0.62^{* *}$ & 42.3 \\
$\mathrm{H}_{2} \mathrm{O}_{2}+$ EQ salt $5 \mu \mathrm{M}$ & $4.79 \pm 0.83$ & 28.5 & $4.20 \pm 0.70$ & 35.0 \\
$\mathrm{H}_{2} \mathrm{O}_{2}+$ EQ salt $10 \mu \mathrm{M}$ & $4.16 \pm 0.65^{* *}$ & 40.4 & $3.62 \pm 0.64^{* *}$ & 47.4 \\
\hline
\end{tabular}

${ }^{a}$ The results are expressed as Olive tail moment mean values \pm S.E.M.

${ }^{\mathrm{b}}$ The reduction (\%) showing antigenotoxicity was calculated using the formula: [(mean score in $\mathrm{A}$ - mean score in $\mathrm{B}) /$ mean score in A-mean score in $\mathrm{C}) \mathrm{x} 100$ ], where $A$ is the treatment with $\mathrm{H}_{2} \mathrm{O}_{2}$, B is the treatment with $\mathrm{H}_{2} \mathrm{O}_{2}$ plus the tested compound, $\mathrm{C}$ is the negative control.

* The statistically significant difference in comparison with the negative control $(\mathrm{P}<0.05)$.

${ }^{* *}$ The statistically significant difference in comparison with the $\mathrm{H}_{2} \mathrm{O}_{2}$ treatment $(\mathrm{P}<0.05)$.

On the other hand, Skolimowska and Wędzisz ${ }^{23}$ analysed the influence of these antioxidants on bacterial cell growth and showed higher effectiveness of EQ in comparison with EQ-HCl.

The micronucleus test revealed that EQ salts neither induced an increase in micronuclei number nor influenced cell divisions significantly (Table 3). The numbers of micronuclei observed after treatments with EQ salts in both donors were always at the negative control level. The values of CPBI did not differ significantly from the control values as well.

In the micronucleus test many genotoxicants are positive when they are used above the concentration where the cytotoxic effects may be observed. In the present study the dose of 50 $\mu \mathrm{M}$ was the highest concentration used although cytotoxicity studies with EQ salts showed that EQ salts, especially EQ-P is not so cytotoxic as pure EQ. ${ }^{10}$ 
Table 3. Number of micronuclei (MN) and CPBI values in human lymphocyte cultures treated with EQ-P or EQ-HCl for $48 \mathrm{~h}$

\begin{tabular}{|c|c|c|c|c|c|}
\hline \multirow[t]{2}{*}{ Donor } & \multirow{2}{*}{$\begin{array}{c}\text { Concentration } \\
(\mu \mathrm{M})\end{array}$} & \multicolumn{2}{|c|}{ EQ-P } & \multicolumn{2}{|c|}{ EQ-HCl } \\
\hline & & $\mathrm{MN}$ & CBPI & MN & CBPI \\
\hline \multirow[t]{5}{*}{ A } & 0 & 9 & 1.89 & 9 & 1.89 \\
\hline & 5 & 9 & 1.70 & 10 & 1.75 \\
\hline & 10 & 9 & 1.75 & 11 & 1.80 \\
\hline & 25 & 8 & 1.78 & 10 & 1.78 \\
\hline & 50 & 8 & 1.75 & 10 & 1.67 \\
\hline \multirow[t]{5}{*}{ B } & 0 & 8 & 2.12 & 8 & 2.12 \\
\hline & 5 & 8 & 2.02 & 7 & 2.02 \\
\hline & 10 & 9 & 1.96 & 8 & 1.94 \\
\hline & 25 & 7 & 1.93 & 8 & 1.99 \\
\hline & 50 & 10 & 1.85 & 4 & 1.93 \\
\hline Total & 0 & $8.5 \pm 0.7$ & $2.00 \pm 0.16$ & $8.5 \pm 0.7$ & $2.00 \pm 0.16$ \\
\hline$(A+B)$ & 5 & $8.5 \pm 0.7$ & $1.86 \pm 0.22$ & $8.5 \pm 2.1$ & $1.88 \pm 0.19$ \\
\hline \multirow[t]{3}{*}{ mean \pm S.D. } & 10 & $9.0 \pm 0.0$ & $1.85 \pm 0.14$ & $9.5 \pm 2.1$ & $1.87 \pm 0.10$ \\
\hline & 25 & $7.5 \pm 0.7$ & $1.86 \pm 0.10$ & $9.0 \pm 1.4$ & $1.89 \pm 0.16$ \\
\hline & 50 & $9.0 \pm 1.4$ & $1.80 \pm 0.07$ & $7.0 \pm 4.2$ & $1.80 \pm 0.19$ \\
\hline
\end{tabular}

$\mathrm{MN}$, micronuclei; CPBI, cytokinesis-block proliferation index.

$\mathrm{CPBI}=\left(\mathrm{M}_{1}+2 \mathrm{M}_{2}+3 \mathrm{M}_{\mathrm{m}}\right) / \mathrm{N}$,

where $M_{1}, M_{2}, M_{m}$ represent the number of cells with one, two nuclei or the number of multinucleate cells, respectively, and $\mathrm{N}$ is the number of cells scored . ${ }^{16}$

Despite relatively low cytotoxicity of EQ-P observed earlier after using higher concentrations than $50 \mu \mathrm{M},{ }^{10}$ cytotoxicity was significant, as not enough cells for analysis with well preserved cytoplasm were obtained. It could be caused by longer treatment (48-h) than in the trypan blue exclusion test (24-h) performed earlier, ${ }^{10}$ which influenced the stability of cell membrane.

The results of antioxidant activities of EQ-P and EQ-HCl. $\mathrm{H}_{2} \mathrm{O}_{2}$ (Table 4) caused an increase in the number of micronuclei and it was observed in experiments performed with cells both donor A and donor B. The treatments with EQ salts led only to a slight, statistically insignificant, reduction in the micronuclei number in comparison with the positive control $\left(\mathrm{H}_{2} \mathrm{O}_{2}\right)$, contrary to pure EQ which used at the concentrations of 5 and $10 \mu \mathrm{M}$ was significantly antioxidative. ${ }^{9}$ Simultaneous treatment of the cultured lymphocytes with $\mathrm{H}_{2} \mathrm{O}_{2}$ and EQ salts did not influence kinetics of cell divisions, since the values of CPBL were not significantly different from the control. 
Table 4. The effects of EQ-P or EQ-HCl treatments on $\mathrm{H}_{2} \mathrm{O}_{2}$ genotoxicity assessed by the micronucleus assay in human lymphocytes

\begin{tabular}{|c|c|c|c|c|c|}
\hline \multirow[t]{2}{*}{ Donor } & \multirow[t]{2}{*}{ Treatment } & \multicolumn{2}{|c|}{ EQ-P } & \multicolumn{2}{|c|}{ EQ-HCl } \\
\hline & & $\mathrm{MN}$ & CBPI & $\mathrm{MN}$ & CBPI \\
\hline \multirow[t]{6}{*}{$\mathrm{A}$} & Control & 9 & 1.56 & 9 & 1.56 \\
\hline & $\mathrm{H}_{2} \mathrm{O}_{2} 75 \mu \mathrm{M}$ & 16 & 1.69 & 16 & 1.69 \\
\hline & $\mathrm{H}_{2} \mathrm{O}_{2}+$ EQ salt $5 \mu \mathrm{M}$ & 12 & 1.45 & 15 & 1.75 \\
\hline & $\mathrm{H}_{2} \mathrm{O}_{2}+$ EQ salt $10 \mu \mathrm{M}$ & 14 & 1.50 & 12 & 1.64 \\
\hline & $\mathrm{H}_{2} \mathrm{O}_{2}+$ EQ salt $25 \mu \mathrm{M}$ & 15 & 1.50 & 12 & 1.62 \\
\hline & $\mathrm{H}_{2} \mathrm{O}_{2}+$ EQ salt $50 \mu \mathrm{M}$ & 16 & 1.50 & 17 & 1.58 \\
\hline \multirow[t]{6}{*}{ B } & Control & 10 & 1.59 & 10 & 1.59 \\
\hline & $\mathrm{H}_{2} \mathrm{O}_{2} 75 \mu \mathrm{M}$ & 20 & 1.52 & 20 & 1.52 \\
\hline & $\mathrm{H}_{2} \mathrm{O}_{2}+$ EQ salt $5 \mu \mathrm{M}$ & 23 & 1.52 & 17 & 1.45 \\
\hline & $\mathrm{H}_{2} \mathrm{O}_{2}+$ EQ salt $10 \mu \mathrm{M}$ & 13 & 1.44 & 19 & 1.55 \\
\hline & $\mathrm{H}_{2} \mathrm{O}_{2}+$ EQ salt $25 \mu \mathrm{M}$ & 20 & 1.50 & 15 & 1.48 \\
\hline & $\mathrm{H}_{2} \mathrm{O}_{2}+$ EQ salt $50 \mu \mathrm{M}$ & 17 & 1.41 & 15 & 1.35 \\
\hline Total & Control & $9.5 \pm 0.7$ & $1.58 \pm 0.02$ & $9.5 \pm 0.7$ & $1.58 \pm 0.02$ \\
\hline$(\mathrm{A}+\mathrm{B})$ & $\mathrm{H}_{2} \mathrm{O}_{2} 75 \mu \mathrm{M}$ & $18.0 \pm 2.8$ & $1.61 \pm 0.12$ & $18.0 \pm 2.8$ & $1.61 \pm 0.12$ \\
\hline mean \pm & $\mathrm{H}_{2} \mathrm{O}_{2}+$ EQ salt $5 \mu \mathrm{M}$ & $17.5 \pm 7.8$ & $1.48 \pm 0.05$ & $16.0 \pm 1.4$ & $1.60 \pm 0.21$ \\
\hline \multirow[t]{3}{*}{ S.D. } & $\mathrm{H}_{2} \mathrm{O}_{2}+$ EQ salt $10 \mu \mathrm{M}$ & $13.5 \pm 0.7$ & $1.47 \pm 0.04$ & $15.5 \pm 4.9$ & $1.60 \pm 0.06$ \\
\hline & $\mathrm{H}_{2} \mathrm{O}_{2}+$ EQ salt $25 \mu \mathrm{M}$ & $17.5 \pm 3.5$ & $1.50 \pm 0.00$ & $13.5 \pm 2.1$ & $1.55 \pm 0.10$ \\
\hline & $\mathrm{H}_{2} \mathrm{O}_{2}+$ EQ salt $50 \mu \mathrm{M}$ & $16.5 \pm 0.7$ & $1.46 \pm 0.07$ & $16.0 \pm 1.4$ & $1.46 \pm 0.16$ \\
\hline
\end{tabular}

$\mathrm{MN}$, micronuclei; CPBI, cytokinesis-block proliferation index.

$\mathrm{CPBI}=\left(\mathrm{M}_{1}+2 \mathrm{M}_{2}+3 \mathrm{M}_{\mathrm{m}}\right) / \mathrm{N}$,

where $\mathrm{M}_{1}, \mathrm{M}_{2}, \mathrm{M}_{\mathrm{m}}$ represent the number of cells with one, two nuclei or the number of multinucleate cells, respectively, and $\mathrm{N}$ is the number of cells scored . ${ }^{15}$

The results obtained in the micronucleus test for EQ salts were negative (similarly as for pure EQ studied earlier ${ }^{9}$ ), as they did not induce increase in the micronuclei number, but in the comet assay induction of DNA fragmentation by the compounds was observed. The different results obtained in the two tests used in the studies were undoubtedly caused by their different sensitivity; it has earlier been shown that the micronucleus test was less sensitive in detecting low levels of DNA damage than the comet assay. ${ }^{24}$ It is also known that the proliferating cells have higher repair capacity than those in $\mathrm{G}_{0}$ phase of the cell cycle, ${ }^{25}$ so primary DNA lesions detected in the comet assay, which probably also took place in the micronucleus assay, could be repaired.

In conclusion, our present and earlier results, in which lower cytotoxicity of EQ salts in comparison with EQ ${ }^{9}$ was observed, showed that converting EQ into salts (phosphate and hydrochloride) influenced its biological properties. On the one hand, cytotoxic and genotoxic 
activities were reduced positively, on the other hand their antioxidant activities, especially those of EQ-P, were also decreased as compared with EQ. It seems that EQ-P and EQ-HCl, being less effective antioxidants than EQ, are not the best alternative for animal feed protection. Therefore new non-toxic antioxidants with high antioxidant activity similar to that of EQ should be searched to replace EQ and in this way to protect animals from its harmful health effects.

\section{Experimental Section}

\section{Chemistry}

General Procedures. All materials were received from commercial suppliers (Sigma-Aldrich, USA; Fluka; Switzerland; POCH - Poland) and were used without further purification. All solvents were redistilled over appropriate drying agents prior to use. Melting points were determined using micro melting point apparatus (Boëtius system) and are uncorrected. FTIR spectra were measured with a spectrophotometer Perkin-Elmer System 2000 FTIR with KBr as reference. The intensity is indicated as follows: $\mathrm{s}$ (strong), $\mathrm{m}$ (medium), w (weak) and b (broad).

All ${ }^{1} \mathrm{H}$ and ${ }^{13} \mathrm{C}$ NMR spectra were obtained on a Varian Gemini-200 BB spectrophotometer at ambient temperature. Chemical shifts were reported as $\delta$-values in parts per million (ppm) relative to $\mathrm{Si}\left(\mathrm{CH}_{3}\right)_{4}$ as relative reference $(\delta=0 \mathrm{ppm})$ and to the solvent as internal reference using to $\mathrm{CDCl}_{3}\left({ }^{13} \mathrm{C}\right.$ NMR as internal standard $\left.\delta=77.0 \mathrm{ppm}\right)$. Coupling constants $(J)$ were reported in Hertz $(\mathrm{Hz})$. Peak multiplicities are indicated as follows: $s$ (singlet), $\mathrm{d}$ (doublet), $\mathrm{t}$ (triplet), q (quartet), quin (quintet), se (sextet), m (multiplet) and b (broad). Multiplicity of carbon signals was determined by DEPT experiments with a phase angle of $135^{\circ}$ : (C) not observed; $(\mathrm{CH})$ positive; $\left(\mathrm{CH}_{2}\right)$ negative; $\left(\mathrm{CH}_{3}\right)$ positive.

Reactions were monitored by TLC, carried out on $0.2 \mathrm{~mm}$ Merck silica gel plates $\left(60 \mathrm{~F}_{254}\right)$ using UV-light, column flash chromatography was carried out on Merck silica gel 60 (0.040 - 0.063 $\mathrm{mm})$. All reactions were performed under argon in oven-dried glassware.

1,2-dihydro-6-ethoxy-2,2,4-trimethylquinoline (EQ). Found $\mathrm{n}_{\mathrm{D}}{ }^{20} 1.570$; IR (film, $\mathrm{cm}^{-1}$ ) $3362 \mathrm{~s}$, $3023 \mathrm{v}, 2973 \mathrm{~s}, 2870 \mathrm{~s}, 1652 \mathrm{v}, 1579 \mathrm{~m}, 1500 \mathrm{~s}, 1477 \mathrm{~s}, 1446 \mathrm{~s}, 1389 \mathrm{~m}, 1381 \mathrm{~m}, 1261 \mathrm{~s}, 1200 \mathrm{~s}, 1155 \mathrm{~s}$, $1116 \mathrm{~m}, 1051 \mathrm{~s}, 956 \mathrm{v}, 930 \mathrm{v}, 869 \mathrm{v}, 804 \mathrm{~m} ;{ }^{1} \mathrm{H}$ NMR in $\mathrm{CDCl}_{3}$ EQ $(2 \%$ solution, wt. $/ \mathrm{v}) \delta_{\mathrm{H}}$ in ppm: 6.69 (dd, EQ-Cㅂ-5; J= 2.7 Hz; J=0.7 Hz, 1H); 6.59 (dd, EQ-Cㅍ-7; J=8.2 Hz; J=2.7 Hz, 1H);

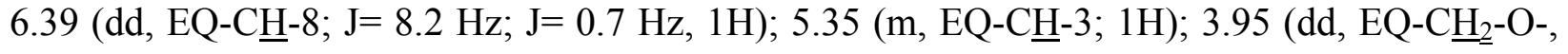

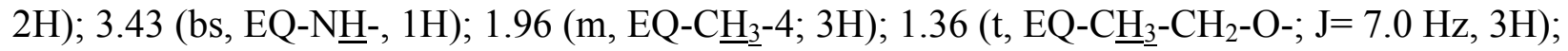
1.24 (s, EQ- $\left.\underline{H}_{3}-2,6 \mathrm{H}\right) ;{ }^{13} \mathrm{C} \mathrm{NMR}$ in $\mathrm{CDCl}_{3}$ EQ (8\% solution) $\delta_{\mathrm{C}}$ in ppm: 151.2 (EQ-C-6); 137.6 (EQ-C-4); 129.5 (EQ-C-3); 128.5 (EQ-C-9); 122.8 (EQ-C-10); 114.6 (EQ-C-8); 113.6 (EQ-C-7); 111.1 (EQ-C-5) ; $64.2\left(\mathrm{EQ}-\underline{\mathrm{CH}}_{2}-\mathrm{O}\right) ; 51.6$ (EQ-C-2); $30.4\left(\mathrm{EQ}-\mathrm{CH}_{3}-4\right) ; 18.5\left(\mathrm{EQ}-\underline{\mathrm{CH}}_{3}-\right.$ 4); $15.0\left(\mathrm{EQ}-\mathrm{CH}_{3}-\mathrm{CH}_{2}-\mathrm{O}-\right)^{;}{ }^{18}$

Ethoxyquin hydrochloride (EQ-HCl). ${ }^{13} \mathrm{C} \mathrm{NMR} \mathrm{w} \mathrm{CDCl}_{3} / \mathrm{CF}_{3}-\mathrm{COOD}(2: 1 ; 10 \% \mathrm{v} / \mathrm{v}) \delta_{\mathrm{C}}$ in ppm: 160,6;131,1;130,0;128,4;123,6;121,8, 118,7;117,2;113,4;112,3; 108,1; 64,2; 576,8; 
23,6; 17,7; 14,3. IR (KBr, cm $\left.{ }^{-1}\right)$ 2978, 2893, 2854, 2641, 2549, 2518, 2468, 1583, 1562, 1500, 1389, 1321, 1259, 1204, 1048, 875.

Ethoxyquin phosphate (EQ-P). EQ-P $\left(\mathrm{CD}_{3} \mathrm{OD}, 10 \% \mathrm{wt} . / \mathrm{v}\right.$ solution) $\delta_{\mathrm{C}}$ in ppm: 131.1 (EQ-C6); 130.0 (EQ-C-9); 128.4 (EQ-C-3); 123.6 (EQ-C-4); 123.9 (EQ-C-10); 121.8 (EQ-C-8); 118.7 (EQ-C-7); 112.7 (EQ-C-5); $64.2\left(\mathrm{EQ}-\underline{\mathrm{CH}}_{2}-\mathrm{O}\right) ; 57.8$ (EQ-C-2); 23.9 and $23.6\left(\mathrm{EQ}-\mathrm{CH}_{3}-4\right) ; 17.7$ $\left(\mathrm{EQ}-\mathrm{CH}_{3}-2\right) ; 14.3$ (EQ- $\left.\underline{\mathrm{CH}}_{3}-\mathrm{CH}_{2}-\mathrm{O}-\right) ; \quad \mathrm{IR}\left(\mathrm{KBr}, \mathrm{cm}^{-1}\right)$ 2978, 2893, 2854, 2641, 2549, 2518, 2468, 1583, 1562, 1500, 1389, 1321, 1259, 1204, 1048, 875; ${ }^{31} \mathrm{P}$ NMR (CD ${ }_{3} \mathrm{OD}$; external standard phosphoric acid in $\delta$ p: 0 ppm; $85 \%$ water solution, wt./v) $\delta$ p: $+4,63$ ppm.

\section{Biological assays}

The tests were performed with the use of lymphocytes isolated from peripheral blood of healthy female non-smoking donors. The isolation of lymphocytes was performed by centrifugation in a density gradient of Histopaque 1077 (Sigma) for $15 \mathrm{~min}$ at $280 \mathrm{x}$ g. The viability of the isolated lymphocytes was measured by trypan blue exclusion assay with the use of $0.4 \%$ trypan blue reagent (Sigma). ${ }^{19}$

The compounds studied were dissolved in the RPMI 1640 medium (Sigma) directly before the use.

To perform genotoxicity studies with comet assay the isolated lymphocytes $\left(2 \times 10^{5}\right.$ cells $\left./ \mathrm{mL}\right)$ were treated with the tested compounds $\left(1 \mathrm{~h}\right.$ at $\left.37^{\circ} \mathrm{C}\right)$ at the final concentrations of $1-25 \mu \mathrm{M}$. To evaluate the antioxidant activity of EQ salts (comet assay) they were added to the lymphocyte suspensions $\left(2 \times 10^{5}\right.$ cells $\left./ \mathrm{mL}\right)$ at the concentrations ranging from 1 to $10 \mu \mathrm{M}$. Immediately after this (within 5 minutes) the cells were treated with hydrogen peroxide (final concentration: 10 $\mu \mathrm{M}$ ) for 5 min on ice. After the treatment the cells were washed in PBS (Sigma) and the viability of the lymphocytes was determined with the use of $0.4 \%$ trypan blue reagent. ${ }^{19}$ The comet assay was performed basically according to Singh et al. ${ }^{16}$ The lymphocytes suspended in $0.75 \%$ low melting point agarose (Serva) were spread onto microscope slides precoated with $0.5 \%$ normal melting point agarose (Serva), covered with coverslips and placed on ice for 5 min. After removing the coverslips the cells were lysed for $1 \mathrm{~h}$ at $4{ }^{\circ} \mathrm{C}$ in a buffer consisting of $2.5 \mathrm{M} \mathrm{NaCl}$, $100 \mathrm{mM}$ EDTA, $10 \mathrm{mM}$ Tris, 1\% N-lauroylsarcosine (pH 10) and 1\% Triton X-100 (all chemicals from Sigma) added just prior to use. After the lysis, DNA was allowed to unwind for $30 \mathrm{~min}\left(4^{\circ} \mathrm{C}\right)$ in alkaline $(\mathrm{pH}>13)$ electrophoresis buffer $(1 \mathrm{mM}$ EDTA, $300 \mathrm{mM} \mathrm{NaOH})$. Electrophoresis was conducted at $25 \mathrm{~V}(0.73 \mathrm{~V} / \mathrm{cm})$ and $300 \mathrm{~mA}$ for $23 \mathrm{~min}$. The slides were

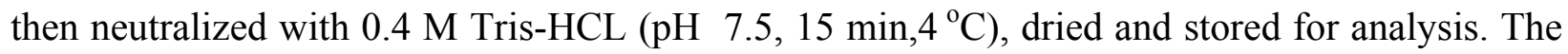
slides were stained with DAPI $(1 \mu \mathrm{g} / \mathrm{mL})$ and the analysis was performed using fluorescence microscope (Olympus BX60F5, $360 \mathrm{~nm}$ filter). Image data were analysed using CASP software. ${ }^{18}$ Fifty cells were randomly selected and analysed from each sample. In each of two experiments 100 cells (50 cells from each sample) were used to evaluate DNA damage for each concentration of the tested compound. The values of Olive tail moment (OTM, the product of the distance between the center of gravity of the head and the tail, and percent of tail DNA) were 
analysed. ${ }^{20}$ Differences between the comet assay mean values were tested for statistical significance using Student's t-test.

The cytokinesis block micronucleus assay was carried out according to the method proposed by Fenech ${ }^{17}$ with slight modifications. Isolated lymphocytes obtained from two donors were placed in RPMI 1640 medium (about $0.8 \times 10^{6}$ cells $/ \mathrm{mL}$ ) supplemented with $15 \%$ of foetal calf serum (sigma), 1\% of penicillin/streptomycin solution (Sigma), 1\% of phytohaemagglutinin M (Difco) and incubated for $24 \mathrm{~h}$ at $37^{\circ} \mathrm{C}$. For genotoxicity studies EQ salts dissolved in RPMI 1640 medium were added to lymphocyte cultures (final concentrations: $5-50 \mu \mathrm{M}$ ) at $24 \mathrm{~h}$ and maintained until cell harvest (the total culture time was $72 \mathrm{~h}$ ). The concentration of $50 \mu \mathrm{M}$ was the highest studied concentration because of toxicity effects observed after higher doses of EQ salts, after which the cell divisions were reduced and only few cells with well preserved cytoplasm were obtained to analysis. To analyse antioxidant activity of the tested compounds hydrogen peroxide $\left(\mathrm{H}_{2} \mathrm{O}_{2}\right.$; Sigma) at the final concentration of $75 \mu \mathrm{M}$ was added to the cultures simultaneously with EQ salts $(5-50 \mu \mathrm{M})$. Cytochalasin-B $(4.5 \mu \mathrm{g} / \mathrm{mL}$; Sigma $)$ was added to the cultures $44 \mathrm{~h}$ after PHA stimulation. The cultures were harvested $28 \mathrm{~h}$ later, giving a total culture time of $72 \mathrm{~h}$. Cells were suspended in $75 \mathrm{mM} \mathrm{KCl}$ for about $3 \mathrm{~min}$ and then fixed in methanolacetic acid $(5: 1, v / v)$. Air dried preparations were made and stained with 3\% Giemsa. For each experimental point, 2000 binucleated cells (BN) with well preserved cytoplasm were scored (1000 cells from replicate cultures of each donor). ${ }^{17}$ Five hundred cells were also scored to calculate a cytokinesis block proliferation index (CPBI) according to the formula:

$\mathrm{CPBI}=\left[\mathrm{M}_{1}+2 \mathrm{M}_{2}+3 \mathrm{M}_{\mathrm{m}}\right] / \mathrm{N}$

where $\mathrm{M}_{1}, \mathrm{M}_{2}, \mathrm{M}_{\mathrm{m}}$ represent the number of cells with one, two nuclei or the number of multinucleate cells, respectively, and $\mathrm{N}$ is the number of cells scored. ${ }^{18}$

\section{Acknowledgements}

This work was supported by the State Committee for Scientific Research (KBN, Poland), grant number 3 PO4C 02124.

\section{References}

1. Little, A. D. Chemical Committee Draft Report, Ethoxyquin, CAS Number 91-53-2. 1990, http://ntp.niehs.nih.gov/index.cfm?objectid=03DB0FE2-EF1D-4E38-4D2D6FB 9637E706C (January 2007).

2. Code of Federal Regulations, Title 21-Food and Drugs, Vol. 6, Part 573-Food additives permitted in feed and drinking water of animals, Sec. 573.380, April 1, 2006.

3. Dzanis, D. A. J. Nutr. 1991, 121, S163.

4. Manson, M. M.; Green, J. A.; Driver, H. E. Carcinogenesis 1987, 8, 723. 
5. De Koning, A. J. Fat Sci. Technol. 1987, 89, 103.

6. Kim, H. L. J. Toxicol. Environ. Health 1985, 15, 663.

7. Błaszczyk, A.; Skolimowski, J. Chem.-Biol. Interact. 2006, 162, 268.

8. Makary, M.; Kim, H. L.; Safe, S.; Womack, J.; Ivie, G. W. Comp. Biochem. Physiol. 1989, 92C, 171.

9. Błaszczyk, A.; Skolimowski, J. Chem.-Biol. Interact. 2006, 162, 70.

10. Błaszczyk, A.; Skolimowski, J. Cell. Mol. Biol. Lett. 2005, 10, 15.

11. Błaszczyk, A.; Skolimowski, J. Acta Pol. Pharm.-Drug Res. 2005, 62, 115.

12. Drewhurst, I. Ethoxyquin JMPR Evaluations, 1998, http://www.inchem.org/documents/jmpr/jmpmono/v098pr09.htm (January 2007).

13. (a) Dorey, G.; Lockhart, B.; Lestage, P.; Casara, P. Bioorg. Med. Chem. Lett. 2000, 10, 935.

(b) De Koning, A. J. Int. J. Food Properties 2002, 5, 451.

14. Clarke, I. P.; Meth-Cohn, O. Arkivoc 2000, (iii), 372.

15. Tung, C. C. Tetrahedron 1963, 19, 1685.

16. Singh, N. P.; McCoy, M. T.; Tice, R. R.; Schneider, E. L. Exp. Cell Res. 1988, 175, 191.

17. Fenech, M. Mutat. Res. 2000, 455, 81.

18. Kirsch-Voldres, M.; Sofuni, T.; Aardema, M.; Albertini, M.; Eastmond, D.; Fenech, M.; Ishidate, M.; Kirchner, S.; Lorge, E.; Morita, T.; Norppa, H.; Surralles, J.; Vanhauwaert, A.; Wakata, A. Mutat. Res. 2003, 540, 153.

19. Freshney, R. I. Culture of Animal Cells: A Manual of Basic Technique, $3^{\text {rd }}$ Ed. Wiley: New York, 1994.

20. Końca, K.; Lankoff, A.; Banasik, A.; Lisowska, H.; Kuszewski, T.; Góźdź, S.; Koza, Z.; Wójcik, A. Mutat. Res. 2003, 534, 20.

21. Błaszczyk, A. Toxicol. Lett. 2006, 163, 77.

22. De Koning, A. J. Int. J. Food Properties 2002, 5, 451.

23. Skolimowska, U.; Wedzisz, A. Bromat. Chem. Toksykol. 2002, 35, 351.

24. He, J. L.; Chen, W. L.; Jin, L. F.; Jin, H. Y. Mutat. Res. 2000, 469, 223.

25. Kalweit, S.; Vasudey, V.; Obe, G. Mutat. Res. 1988, 207, 41. 